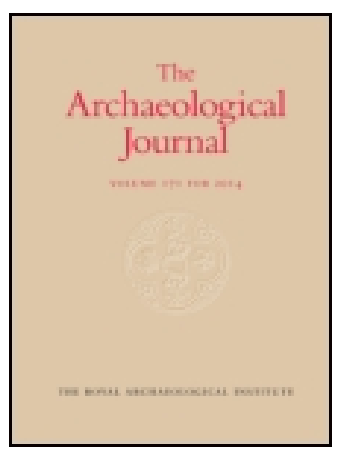

Archaeological Journal

\title{
A Few Words On Towers and Spires
}

\section{Sir C. H.J. Anderson Bart}

To cite this article: Sir C. H. J. Anderson Bart (1879) A Few Words On Towers and Spires, Archaeological Journal, 36:1, 373-377, DOI: 10.1080/00665983.1879.10851891

To link to this article: http://dx.doi.org/10.1080/00665983.1879.10851891

曲 Published online: 14 Jul 2014.

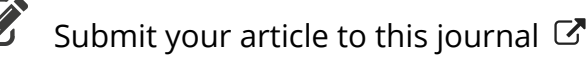

ЏII Article views: 2

Q View related articles 두 


\title{
A FEW WORDS ON TOWERS AND SPIRES.
}

\author{
By Sir C. H. J. ANDERSON, Bart.
}

Babel, as far as we know, seems to have been the parent of all towers. The desire of man to get nearer the sky, to command an extensive view for watching or protection, or to memorialize the lead, seems to have existed from the earliest times. The Pyramids are the most ancient and lofty piles now existing, raised in a flat country, as is so frequently the case. Till the introduction of Christianity, towers appear to have been rare, except as appendages to the walls of fortified cities, or as pharoses or lighthouses. A circular tower as early as the time of Justinian is said to exist at Ravenna. Although the use of bell towers or campaniles became common, many were civic monuments, like those of St. Mark, and probably the Giralda at Seville, and some of the hotels de ville in France and Belgium, but in most cases they were ecclesiastical structures and near the churches. In Italy they are often detached, as at Parma, Florence, Sienna, Verona, Pisa, etc. In the North of Germany, in France, and England, with few exceptions, they form part of the church itself. We have the Lombard towers developed in the Norman western steeples, as the central tower represents the Byzantine dome.

The round towers in Ireland are said to be the earliest ecclesiastical specimens of detached towers in the North of Europe. They could scarcely be intended for bells; more likely for observation or for lights, having small windows at the top, lut no accessible roof. The Lombard towers usually consist of stages, lighted by round-headed windows with a pilaster between, with low inacessible roofs. But where the outside roof was intended as a platform for olserratin, parapets became necessary, and how to finish a tower so as to make it ornamental, became a subject requiring much thought, which may account for the number of unfinished towers, and the few, comparatively speaking, which please the eye; doubtless in many cases, as now, short funds stopped the work, which was afterwards carried in later styles up to the parapet, and then left incomplete.

Of the Italian campaniles there can be no doubt that Florence is far the finest, in true perpendicular, grand in height and proportions, and without that appearance of splitting at the top, as it is well termed by Sir Edmund Beckett in his book on building; it probably tapers slightly, though imperceptibly. Sienna, Parma, St. Zenone at Verona are good specimens, thongh not graceful, and in the Black Forest the surviving west tower of the Abbey of Hirshau is a noble example. The falling tower of Pisa, even if it were straight, could never have been a satisfactory example, i.e. as a tower. The finishing of Early Norman church towers in England was often a plain parapet, and how preferable that is to the later battlements may be seen in St. Peter's at Gowts, at Lincoln. 
One cannot help wondering why this plain and symmetrical steeple has never been copied. In cathedrals the Norman towers were often finished with wooden spires covered with lead, as Durham, Southwell, the north tower of Canterbury (now pulled down) and possibly the western towers of Lincoln before the later additions; but the common-place battlements and pinnacles seem to have been fashionable, and to have been added in later times, as at Southwell, Durham, Exeter, Worksop and elsewhere. Complete Early English towers are rare; the west towers of Ripon, which had learlen spires, are good examples; and also West Walton and Sutton St. Mary's, both detached, and the latter surmounted by a leaden spire and pinnacles; but the lancet style, as a rule, is not adapted for effective belfry windows.

Erery tower has a physiognomy, of which the belfry windows may be called the eyes, and the hood moulding the eyebrows. When the tower is narrow a single belfry window of two lights is preferable to one with three, but double windows are infinitely more effective when the tower is sufficiently wide to admit of them, and the bolder the hood moulding the better, e.g., compare the three towers of Lincoln (especially the western towers), the centre towers of York, Canterbury, Gloucester, Worcester, Durham, the west towers of Wells, of Newark, Grantham and Louth churches, with the west towers of York Minster, the towers of Boston, Derby, Fountain's Abbey, \&c. I place Beverley Minster towers by themselves, being too narrow on the west and eastern faces for double windows, and perhaps also on the north and south sides, which are a trifle wider, but which, taken as a whole, are models of beauty and good proportion.

Much depends on the space between the belfry windows and the top of the tower. As a rule, it will be found that the old architects seldom failed to hit the right spot. Compare the Victoria tower at Westminster with the great tower of York. In the former are three belfry windows in a row, where, if one may venture to criticise, two would have been far preferable, and these are placed too much below the parapet. If the tower had two windows, like those in the great tower of York, some feet higher up, the effect would be far better. If the great coarse single light window at Boston was replaced by two windows like those in the stage below, it would be a great improvement.

Some of the finest towers and spires are of mixed styles, i.e. Lincoln, Wells, Ely, Norwich, Newark, Grantham, St. Mary's Stamford, \&c. York, Beverley, Boston, Louth, Lichfield, Worcester, Canterbury centre tower, Gloucester, St. Stephen's Bristol, Huish Episcopi and many of the Somerset churches, are of one style and chiefly Perpendicular. The west towers of Lincoln are among the mast remarkable, because, though neither straight nor uniform, there are none which more completely satisfy the eye. This is owing to the exceeding elegance of the double belfry windows and hood mouldings; the bold staircase buttresses, which produce unusual depth of light and shade ; the pinnacles, which are leaden spirelets rising out of coronas; and to the position of the towers, not springing from the ground, but behind the broad screen front on the west, and growing, as it were, like gigantic turrets out of the picturesque gables of Norman work and the flanking chapels below, on the north, south and east. If carried downwards, even though buttressed, to the ground, so as to form a portion of the façade, like York, Beverley and others, they 
would appear topheavy and out of proportion. One only regrets the absence of the leaden spires, which were taken down in 1808 .

The outline of these towers is irregular ; to correct this, the coronals of the pinnacles, copied from those on the great tower, are made to project over the stone work, except on the western side of the south-west tower, where the pinnacles are set crooked, the object being to make them rake in line with those of the northern tower, and so to cheat the eye. The coronals are made of oak carved, and the lead hammered on, to shew the indentation, and the pinnacles slightly and somewhat irregularly tapered. Fortunately when repaired a few years ago, the original lines were followed, but the lead was painted a dark brown, which contrasts badly with the stone work and the unpainted pinnacles on the great tower. One cannot but suppose that the progress of these works was most carefully watched, and probably shams set up to test the effect before the work was completed, for we know that the old workmen had no such finished designs as we see in the Royal Academy.

The great tower of Lincoln, as completed, is a Decorated story upon an Early English foundation, and a work of great boldness and beauty. It consists of two narrow walls, tied together by stone and iron, leaving a considerable space between, in order to diminish the weight, and was surmounted by a lofty leaden spire (blown down about the time of the Reformation) and four leaden pinnacles, which now remain. The original parapet consisted probably of little more than the crockets of the canopies over the belfry windows, the present open work havins been put up by Essex in the last century, and though it looks well from below is coarse in execution.

It is worth while to compare this tower, which looks equally well from all distances and on all sides, with the larger and more elaborate Victoria Tower at Westminster, which, though imposing at a distance, appears when viewed near broader at the top than at the bottom. The reason is that it is the same width throughout. The Lincoln tower is gathered in two and a half inches twenty-four feet from the summit; it can only be seen with a good glass; from which wo learn on what trifles in measurement, more or less, symmetrical proportion depends. It is to be noticed that the pinnacles on the tower are rather steeper on the inward side, which was doubtless intended to assist the pyramidal effect of the great spire in the centre, as the flying buttresses do at Louth, uniting the pinnacles (too large by themselves) to the spire, and binding the whole together into the finest pyramid in England, except the queen of spires at Salisbury. Besides other large spires, Grantham, Coventry, Newark, Heckington, W'itttlesea, Yaxley, Leadenham, Ewerby, etc., may be named, and specially Stanion in Northants, a most lovely example of perfect form, combined with simplicity.

Even before the Great Fire, London does not appear to have possessed a single fine tower or spire, except St. Paul's, which, judging from Hollar's views, must have owed its grandeur to size and height, for except the flying buttresses there seems to have been no exuberance of ornament, which, after all, is but a secondary element in architectural beauty, when compared with symmetrical proportion, and it is remarkable how much money is often wasted on the former, to the neglect of the latter.

The only old towers of any size remaining are those of St. Mary Overy, in.Southwark, and Christ Church, near the Holborn Viaduct, and 
both are spoiled by the disproportionate height of the pinnacles. Whether these are original I do not know. Bath Abbey and Pershore have been spoilt by additions of the same kind within the last fifty years. It is to be feared that Magclalen Tower at Oxford has been made a plea for overgrown pinnacles. That fine tower has been, I think, overrated. The space between the belfry windows is rather too wide, and the tower itself slightly out of plumb, like St. Mary-le-Bow; but though the pimnacles are large they are not exaggerated like many of their professed copies. The tower of Merton has not received the praise it deserves, whilst St. Mary's has been lauded as a whole, when its chief merit is due to that exquisite portion which unites a heavy and stumpy tower to a somewhat too slender spire. The plain, well-proportioned tower and broach spire of Christ Church ought not to be passed without commendation.

Reverting to pinmacles: it is remarkable how often a tower looks better without them, e.f. the great tower of York Minster. Doubtless a seconcl story was intended above the lanthorn, as at Howden and Durham, and the work was stopped, probably from uncertainty as to the capability of the four central piers to bear the additional weight, for I believe though they look so solid and grand, they are really Norman work cased, and the mortar used by the Normans was frequently of inferior quality. If the upper story, at York had been added, there would have been pinnacles the bases of which may be seen. But no one, I think, would wish the tower as it is, so simple in its decoration, so broad, square, and solemn, from every point of view, to have pinnacles added to it. Nor, indeed, in my opinion, would Durham or Howden be improved by them; or the western tower at Wells, which appear incomplete, and were perhaps intended to have leaden spires.

The clock tower at Westminster is simply a handsome kitchen clock in stone, and the same may be said of the Midland Railway clock tower, and that of the Town Hall in Manchester. Unless a clock is intended to be lighted at night, when of course there must be a face with a flat surface, it seems a mistake to combine it with the architecture, for it can harlly be clone without injury to the latter. The clock face at Mechlin, one of the granclest towers on the Continent, is, if I am not mistaken, of open metal work, showing only the hands and figures; but the modern fashion is to adapt the gabled spires for the clock, by projecting and ornamenting the stone work beyond the tower walls, thereby destroring its proportions and dignity. How grand gabled towers and spires are almost without ornament, may be seen at the Marie Kirk, Lubeck, ant other brick churches in that wonderful city. Of the modern churches in London, however picturesque they appear en masse at a distance, they are not objects for imitation. St. N Hchael's, Cornhill, is the best proportioned tower, but the details are bad. St. Bride's is the most effective spire, if spire it can be called which is merely a nest of little templets piled upon each other, and crowned by a small obelisk. As for the rest they need not be named. Of the churches built within the last forty years there are some with spires of consiclerable merit, e.g. St. John's, Vauxhall, with a spire rising from the cross, reminding one of Newark and Grantham, than which no better examples could be followel. There may be others unknown to me. Some have been failures from the want of funds, and the foolish desire of committees to have the tower and spire completed 
at once; but in many cases greater success would have been achieved if, before spire or pinnacles were proceeded with, wooden shams had been fixed, to see the effect, bearing in mind, what may be considered an invariable maxim, that a few feet longer or shorter may make all the difference in a spire and a few inches in pinnacles, or, as has been shewn at Lincoln, even in a tower 270 feet high and forty feet in diameter ; had this been done at Bridlington, we might have seen a more successful completion of the otherwise careful restoration of the priory church; but of the new towers, I, for one, will not venture to speak, when there were such guides to go by in the neighbouring Minster of Beverley, the towers of which might serve as models, if ever those frightful steeples of the Royal Abbey should be rebuilt, and it would be no insult to the memory of Wren, so long as St. Paul's remains the magnificent and worthy monument of his great genius. 